\title{
Pencegahan Perkawinan Dini dan Sirri Melalui Collaborative Governance Berbasis Gender di Kabupaten Pati
}

\author{
Siti Malaiha Dewi, Rahayu, Kismartini, Tri Yuniningsih \\ Universitas Diponegoro \\ dewimalaiha@yahoo.com; rahayu_undip@yahoo.com; kis_ \\ martini@yahoo.com; triyuniningsih@yahoo.com
}

\section{ABSTRAK}

Pernikahan dini di pedesaaan marak terjadi termasuk di Desa Prawoto, Kecamatan Sukolilo, Kabupaten Pati. Sebagian besar perkawinan dilakukan secara sirri, selebihnya dilakukan secara tercatat melalui proses dispensasi nikah. Berbagai upaya pencegahan pernikahan di bawah umur sudah dilakukan terutama oleh pihak KUA Sukolilo dengan melakukan penolakan secara institusional melalui pelaksanaan kebijakan pembatasan usia minimal perkawinan dan pendekatan terhadap tokoh agama yang berperan menikahkan mereka secara sirri, tetapi hasilnya belum signifikan, bahkan banyak persoalan kesenjangan gender yang terjadi dalam pelaksanaan kebijakan tersebut setelah dianalisis menggunakan Gender Analysis Pathway. Maka collaborative governance berbasis gender menjadi solusi alternatifnya dengan melibatkan masyarakat, pemuda, tokoh agama, tokoh perempuan, Ketua RT, Kepala Desa, Kecamatan, KUA, dan Pengadilan Agama.

Kata Kunci:Perkawinan Dini dan Sirri, Collaborative Governance Berbasis Gender, Ploso Kerep. 


\section{ABSTRACT}

The background of this paper begins of the high number of early marriages that still occur in Prawoto Village, Sukolilo District, Pati Regency. Most of marriages are performed in Sirri and the rest is recorded through a marriage dispensation process. Various efforts to prevent the underage marriages have been carried out mainly by KUA Sukolilo by institutionally rejecting the implementation of a policy of limiting the minimum age of marriage and the approach to religious leaders who play a role in marrying them in sirri method, but the results have not been significant, even many issues of gender disparities occur in the implementing of the policy after being analyzed by using the Gender Analysis Pathway. Therefore gender-based collaborative governance can be an alternative solution by involving the community, religious leaders, women leaders, RT heads, Village Heads, Districts, KUA, and Religious Courts.

Keyword: Sirri and Early marriage, Gender Based Collaborative Governance, Ploso Kerep village.

\section{A. Pendahuluan}

Undang - undang Nomor 1 Tahun 1974 tentang Perkawinan telah diberlakukan sejak 45 tahun yang lalu. Seharusnya, karena telah berlaku berpuluh - puluh tahun, isi dan materi undang-undang tersebut dipatuhi oleh masyarakat di seluruh penjuru nusantara. Namun, kenyataanya ada bagian undang-undang tersebut yang tidak dipatuhi yaitu pasal 7 ayat (1) yang secara khusus mengatur batas usia minimal perkawinan 19 tahun bagi calon pengantin laki-laki dan 16 tahun bagi calon perempuan. Ketentuan tersebut kemudian mengalami perubahan dimana baik calon pengantin laki-laki maupun perempuan batas minimalnya adalah 19 tahun dan 
tertuang secara resmi dalam Undang -undang Nomor 16 Tahun 2019.

Ketidaktaatan atas pembatasan minimal usia perkawinan sebagaimana diatur dalam UU Perkawinan di atas, terlihat nyata dari laporan BPS Tahun 2017 yang menunjukkan bahwa angka pernikahan anak (yaitu perkawinan dimana pasangan pengantin laki-laki dan perempuan berusia di bawah 18 tahun) termasuk berada pada peringkat yang tinggi dengan tingkat prevalensinya yaitu 25, 71 persen dan terjadi merata hampir di seluruh provinsi di Indonesia. Lebih mencengangkan lagi, tidak hanya tinggi tetapi jika dilihat dari data pilahnya (jenis kelaminya) jumlah anak perempuan jumlahnya lebih tinggi yaitu satu dari empat orang anak perempuan di Indonesia menjadi korban pernikahan usia anak atau sekitar 340.000 anak perempuan setiap tahunnya dan diantaranya terdapat 50.000 anak perempuan yang mengalami perkawinan di usia kurang dari 15 tahun (Statistik, 2017, hal. 1-2). Berdasar data tersebut, maka UNDESA (United National Development Economic and Sosial Affair) menempatkan Indonesia pada posisi ketujuh dunia dan posisi kedua se-ASEAN sebagai negara dengan pernikahan anak yang tinggi. Maka, Kementerian Perempuan dan Anak (KPPA) menganggap Indonesia sebagai negara yang mengalami "Darurat Perkawinan Anak" (KPPA, 2016, hal. 1)

Selain data statistik di atas, hasil penelitian Puslitbang Keagamaan Republik Indonesia, Kementerian Agama pada Tahun 2013 pun menunjukkan bahwa perkawinan dini masih secara terus menerus dipraktekkan di berbagai wilayah di Indonesia. Penelitian ini mengambil sampel di tujuh propinsi yaitu Provinsi Banten, Jawa Barat, Jawa Tengah, Jawa Timur, Daerah Istimewa Yogyakarta, Nusa Tenggara Barat, dan Kalimantan. Hasilnya menunjukkan bahwa pernikahan dini sudah menjadi "tradisi" yang 
berakar kuat. Maka, Kustini, dkk menyimpulkan bahwa data kuantitatif tentang pernikahan dini yang tercatat di Kementerian Agama maupun di BPS dianggap sebagai fenomena gunung es yang nampaknya sedikit karena hanya nampak di ujungnya saja. Namun, kenyataannya terdapat lebih banyak perkawinan dini yang dipraktikkan secara sirri atau tidak dicatatkan di KUA (Kustini, 2013, hal. XIV).

Fenomena yang hampi sama dengan hasil penelitian di atas pun terjadi di Kabupaten Pati tepatnya di Dukuh Ploso Kerep, Desa Prawoto, Kecamatan Sukolilo. Mayoritas penduduk di sana menikah pada usia SD dan SMP dan dilakukan secara sirri. Meski sirri, prosesi pernikahan yang dilaksanakan tidak berbeda dengan pernikahan tercatat. Ada resepsi, ada rame-rame, ada gawe yang mengundang banyak orang, bahkan tidak jarang kerbau sebagai kebanggaan mereka juga disembelih sebagai rasa syukur atas terlaksananya pernikahan. Bedanya, dalam prosesi ijab qobul tidak dihadiri dan dinikahkan oleh pihak KUA, tetapi hanya dihadiri dan dinikahkan oleh tokoh agama atau kyai saja (Dewi, 2016).

Faktor yang menjadi penyebab perkawinan dini di Dukuh Ploso Kerep diantaranya adalah adanya nilai yang diyakini secara kuat oleh masyarakat dan berlaku secara turun temurun sampai saat ini yaitu bahwa "semakin dini anak perempuan dinikahkan adalah hal yang membanggakan, sebaliknya semakin berusia seorang anak hanya memalukan keluarga". Begitu juga berlaku dengan anak laki-laki, "cah lanang yen wis kuat ngangkat watu, wis wayahi rabi" (anak laki-laki jika sudah mampu mengangkat batu sudah saatnya menikah). (Dewi, 2016)

Perasaan bangga sebagaimana diuraikan di atas ternyata juga didukung oleh pemahaman mereka terhadap satu prinsip "Darul mafasid muqodamun a'la jalbil masholih" 
yang artinya lebih baik mendahulukan menolak keburukan daripada mengejar kemaslahatan, maka masyarakat di sana akan cepat-cepat menikahkan anak-anak mereka daripada terjadi perzinaan. Jadi, dapat disimpulkan kalau mereka sangat sadar bahwa dengan menikahkan anaknya pada usia dini adalah hal yang melanggar aturan negara khususnya soal batas usia perkawinan tetapi mereka berpendapat bahwa lebih baik melanggar aturan negara daripada anak mereka melakukan perzinahan. (Dewi, 2016)

Sebenarnya, pihak Kantor Urusan Agama (KUA) dalam hal ini KUA Sukolilo II sudah melakukan berbagai upaya untuk mencegah terjadinya pernikahan dini, diantaranya dengan menolak secara tegas jika ada pengajuan pernikahan yang tidak memenuhi ketentuan yang berlaku. Upaya lainya adalah dengan cara mendekati dan mengumpulkan tokoh agama untuk diajak menalar tujuan pernikahan bukan hanya ngamar atau soal seksual saja tapi ada tujuan jangka panjang yang sangat mulia. Namun, berbagai upaya KUA belum menunjukkan hasil yang signifikan. Pernikahan sikum dan dini masih saja dipraktikkan. maka, tulisan ini akan mengungkap bagaimana pelaksanaan kebijakan pembatasan usia minimal perkawinan dan mengidentifikasi faktor-faktor yang menghambat pelaksanaan kebijakan tersebut sehingga dapat dirumuskan model pelaksanaan kebijakan yang lebih efektif.

Guna menjawab pertayaan-pertanyaan di atas, observasi, wawancara, dokumentasi, dan triangulasi digunakan dalam pengumpulan data pada penelitian yang berjenis lapangan dan menggunakan pendekatan kualitatif ini. Sedangkan analisa data digunakan Gender Analysis Pathway (GAP) yang melihat sejauh mana laki-laki dan perempuan memperoleh akses, kontrol, partisipasi, dan manfaat dalam pelaksanaan kebijakan pembatasan 
usia minimal perkawinan sehingga dapat ditemukenali persoalan gender sekaligus disusun ulang model kebijakan pembatasan usia minimal perkawinan yang mampu memperkecil bahkan menghapus kesenjangan gender (Bappenas \& KPP, 2007, hal. 6).

Penelitian dan tulisan tentang pernikahan dini memang sudah banyak, diantaranya dilakukan oleh: Pertama, M. Niaz Asadullah \& Zaki Wahhaj, berjudul "Child Marriage Law and Freedom of Choice in Bangladesh". Hasilnya menunjukkan bahwa $83 \%$ pernikahan di Bangladesh merupakan pernikahan dengan sistem perjodohan, di mana 39\% menikah di usia 15-an, dan 61\% menikah di usia 18-an (Asadullah, M. Niaz; Wahhaj, 2016, hal. 24-26); Kedua, hasil penelitian Robert Jensen and Rebecca Thornton dengan judul "Early Female Marriage in the Developing World". Penelitian ini bertujuan untuk mengidentifikasi pola dan trend pernikahan dini di negara berkembang. Salah satu hasilnya menunjukkan bahwa pernikahan dini berkorelasi dengan rendahnya tingkat pendidikan (Jensen \& Thornton, 2014); Ketiga, Laura Stark, dengan judul tulisan "Early marriage and cultural constructions of adulthood in two slums in . Dar es Salaam". Tujuanya adalah untuk mengidentifikasi faktor pendorong pernikahan dini pada masyarakat pedesaan di Tanzania. Salah satu temuannya adalah: 1) kemiskinan merupakan faktor penyebab utama terjadinya pernikahan dini; 2) Anak-anak di daerah perang memiliki kerentanan yang tinggi terhadap tindakan eksploitasi seksual; 3) Pemerintah sedang dalam proses meninjau kembali UU Nasional untuk memberikan perlindungan kepada anak secara lebih komperehensif; 4) LSM dan kelompok HAM berkomitmen tinggi untuk secara progresif melindungi hak-hak anak; 5) Otoritas agama bersikap kritis atas pernikahan anak. Walaupun penelitian ini berbeda dengan penelitian yang dilakukan penulis, 
namun temuan penelitian ini dapat dipergunakan sebagai acuan dalam menyusun model implementasi kebijakan pencegahan pernikahan dini dengan melibatkan LSM dan kelompok pejuang HAM, serta otoritas agama (Mikhail, 2010, hal. 51-74)

Mayoritas tulisan-tulisan yang telah diurai di atas, perspektif sosiologi digunakan untuk melihat persoalan pernikahan dini. Disinilah perbedaan tulisan penulis yang melihat pernikahan dini dari perspektif administrasi negara.

\section{B. Pembahasan}

\section{Batas Usia Minimal Perkawinan Menurut Hukum Positif dan Hukum Islam}

Perkawinan dalam Undang - undang Perkawinan No. 1 Tahun 1974 pasal 1 didefinisikan sebagai ikatan lahir dan batin antara seorang laki-laki dan perempuan sebagai suami isteri dengan tujuan membentuk keluarga (rumah tangga) yang bahagia dan kekal berdasarkan Ketuhanan Yang Maha Esa. Namun, Ikatan lahir dan batin sebagaimana tersebut pada pasal 1 Undang-undang Perkawinan tersebut ternyata tidak menjamin kekalnya perkawinan dan terjaminya hak - hak suami dan istri dapat terpenuhi. Diperlukan adanya aturan yang mengatur halhal terkait dalam perkawinan.

Pasal-pasal yang dimaksudkan untuk mengekalkan ikatan baik lahir maupun batin antara suami dan istri dalam keluarga antara lain pasal 7 ayat (1) yang mengatur batas minimal pernikahan, yaitu 19 tahun bagi laki-laki dan 16 tahun bagi perempuan. Pasal ini kemudian direvisi pada Tahun 2019 dimana usia minimal perkawinan baik laki-laki maupun perempuan adalah Sembilan belas tahun. Pasal 
lain yang member rambu-rambu perkawinan adalah pasal 6 ayat (2) disebutkan bahwa meski sudah melampaui batas usia minimal, tetapi perkawinan yang belum mencapai umur 21 tahun harus mendapat izin dari kedua orang tua dalam bentuk izin tertulis yang harus termuat dalam formulir model N5 dimana orang tua atau wali harus memberikan tanda tangan dan nama terang, sebagaimana juga tertuang dalam Peraturan Menteri Agama No.11 tahun 2007 tentang Pencatatan Nikah Bab IV pasal 7 "Apabila seorang calon mempelai belum mencapai umur 21 (dua puluh satu) tahun, harus mendapat izin tertulis dari orang tua".

Bagaimana halnya jika ada calon suami dan calon istri yang berusia di bawah ketentuan undang-undang di atas? Pada Pasal 7 ayat (2) dan Peraturan Menteri Agama No. 11 tahun 2007 tentang Pencatatan Nikah Bab IV pasal 8 disebutkan apabila seorang suami belum mencapai umur sesuai dengan ketentuan, maka harus mendapat dispensasi dari dari pengadilan agama.

Menurut SF. Marbun dan Moh. Mahfud M.D dispensasi diartikan sebagai perbuatan yang menyebabkan suatu peraturan perundang-undangan menjadi tidak berlaku karena sesuatu hal yang sangat istimewa dan memenuhi syarat-syarat tertentu yang ditetapkan dalam undang-undang yang berkaitan (Marbun, S.F \& Mahfud, 2009, hal. 94). Sedangkan menurut Sutendi (2010, hal. 178) dinyatakan bahwa dispensasi bertujuan untuk menembus rintangan yang sebetulnya secara normal tidak diizinkan, namun karena ada alasan-alasan yang bersifat khusus maka diperbolehkan untuk dilakukan.

Definisi dispensasi di atas menunjukkan bahwa perkawinan dini dilarang, kecuali ada peristiwa konkrit yang menyebabkan pejabat administrasi negara dalam hal ini pengadilan agama maka dapat diberikan izin atas permohonan para pihak. 
Adapun syarat-syarat dan prosedur dispensasi nikah di bawah umur adalah sebagai berikut:

1. Kedua orang tua (ayah dan ibu) calon mempelai yang masih di bawah umur, yang masing-masing sebagai pemohon 1 dan pemohon 2 mengajukan permohonan secara tertulis ke pengadilan agama;

2. Permohonan diajukan ke Pengadilan Agama di tempat tinggal para pemohon;

3. Permohonan harus memuat: a. Identitas para pihak (ayah sebagai pemohon I dan Ibu sebagai pemohon 2); b. Posita, yaitu alas an atau dalil yang mendasari diajukanya permohonan serta identitas calon suami dan istri; dan c. Petitum, yaitu hal yang dimohon putusanya dari pengadilan.

Setelah dokumen ataupun alat bukti dalam perkara dispenssasi nikah lengkap, maka hakim akan memutuskan perkara tersebut.

Kembali soal batas usia minimal perkawinan, hukum Islam tidak mengatur secara konkret tentang hal tersebut. Hanya saja, dalam Al Quran diisyaratkan bahwa orang yang akan melangsungkan perkawinan haruslah yang siap dan mampu, sebagaimana firman Allah SWT dalam Surat An Nur (24) ayat 32 yang menurut M. Qurais Shihab kata "Yang layak nikah" adalah yang mampu secara mental dan spiritual untuk membina rumah tangga (Chandra, 2018, hal. 134) sebagaimana juga dalam Hadis Rasulullah SAW, sebagai berikut: 


$$
\begin{aligned}
& \text { عن عبد الرحمن بن يزيد قال دخلت مع علقمة ولأسود على عبدالله فقال عبد اللّه كنا مع }
\end{aligned}
$$

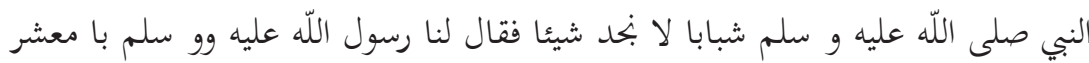

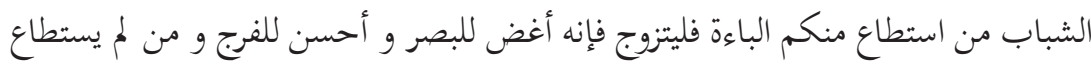

$$
\begin{aligned}
& \text { فعليه بالصيام فإنه له وجاء (رواه البخاري) }
\end{aligned}
$$

Artinya: "Dari Abdurrahman bin Yazid, dia berkata: "Aku masuk bersama al-Qomah dan Al-Aswad ke rumah Abdullah, dia berkata: "Ketika aku bersama Nabi SAW serta para pemuda dan kami tidak menemukan orang lain, Rasulullah SAW bersabda kepada kami, "Wahai para pemuda barang siapa di antara kamu telah mampu berumah tangga, maka nikahlah, karena nikah dapat menundukkan pandangan dan memelihara kemaluan, dan barangsiapa belum mampu, maka hendaklah berpuasa, maka yang demikian itu dapat mengendalikan hawa nafsu". (HR. Bukhari).

Secara eksplisit Al Quran dan Hadis di atas mengakui bahwa kedewasaan sangat penting dalam perkawinan. Meskipun, ukuran dewasa yaitu baligh, para ulama berbeda pendapat. Ulama Syafiiyah, contohnya. Anak laki-laki dan perempuan dianggap baligh apabila telah berusia 15 tahun. Sedangkan ulama Hanafiyah, anak laki-laki dianggap baligh bila berusia 18 tahun dan anak perempuan 17 tahun. Golongan Imamiyah anak laki-laki dianggap baligh bila berusia 15 tahun dan anak perempuan 9 tahun. Golongan ini melandaskan pendapatnya pada hadis pernikahan Rasulullah SAW, sebagai berikut:

$$
\text { عنت عائشة قالت تزوجها رسول اللّه صلى الله عليه وسلم وهي بنت ست وببنى بها وهي }
$$

Artinya: "Dari Aisyah r.a. berkata: Rasulullah SAW menikahiku pada saat usia 6 tahun dan hidup bersamaku pada usia 9 tahun dan beliau wafat saat usiaku 18 tahun (HR. Muslim). 
Majelis Ulama Indonesia (MUI) memberikan fatwa bahwa usia kelayakan pernikahan adalah usia kecakapan berbuat atau ahliyatul ada' dan kecakapan menerima hak atau ahliyatul wujub. Kecakapan berbuat merupakan sifat kecakapan bertindak hukum seseorang yang telah dianggap sempurna untuk mempertanggungjawabkan seluruh perbuatanya, baik perbuatan yang bersifat positip maupun negatif. Adapun ahliyatul wujub merupakan sifat kecakapan seseorang untuk menerima hak-hak yang menjadi haknya. Dengan demikian huum islam tidak menentukan batas usia menikah dan kedewasaan melalui umur melainkan dengan ukuran telah baligh dan mukalallaf (MUI, 2009, hal. 78).

\section{Implementasi Kebijakan Pembatasan Usia Minimal Perkawinan}

Definisi implementasi kebijakan menurut Van Meter dan VAN Horn dalam Dwidjowijoto (2006, hal. 128) adalah serangkaian tindakan yang dilakukan oleh individuindividu ataupun kelompok-kelompok baik pemerintah maupun swasta yang diarahkan untuk mencapai tujuantujuan yang telah ditetapkana. Tindakan-tindakan ini mencakup usaha-usaha untuk mengubah keputusankeputusan menjadi tindakan-tindakan operasional dalam kurun waktu tertentu maupun dalam rangka melanjutkan usaha-usaha untuk mencapai perubahan-perubahan besar dan kecil yang ditetapkan oleh keputusan-keputusan kebijakan.

Meminjam definisi Van Meter \& Van Horn di atas maka implementasi Undang-undang Perkawinan No. 1 Tahun 1974 pasal 7 ayat (1) dan telah direvisi menjadi Undang-undang Perkawinan No. 16 Tahun 2019 tentang pembatasan usia minimal perkawinan ini terfokus pada 
aktivitas-aktivitas atau kegiatan-kegiatan yang dilakukan oleh badan pelaksana untuk menjalankan keputusan kebijakan yang telah ditetapkan dan mengidentifikasi kekuatan-kekuatan yang menentukan dampak sebuah kebijakan.

Badan pelaksana yang dimaksudkan untuk menjalankan UU tersebut di atas adalah KUA Kecamatan Sukolilo sebagai leader sector. Sedangkan institusi atau badan pelaksana lain yang terlibat adalah seperti ketua RT/RW, kepala dusun, Kepala desa/kelurahan, pihak perbankan, puskesmas, dan Pengadilan Agama Kabupaten Pati jika perkawinan diajukan melalui dispensasi nikah. Lebih jelas alur pengajuan nikah dan badan pelaksananya dapat dilihat pada gambar di bawah ini.

Gambar 1. Alur Pengajuan Pernikahan \& Badan Pelaksana

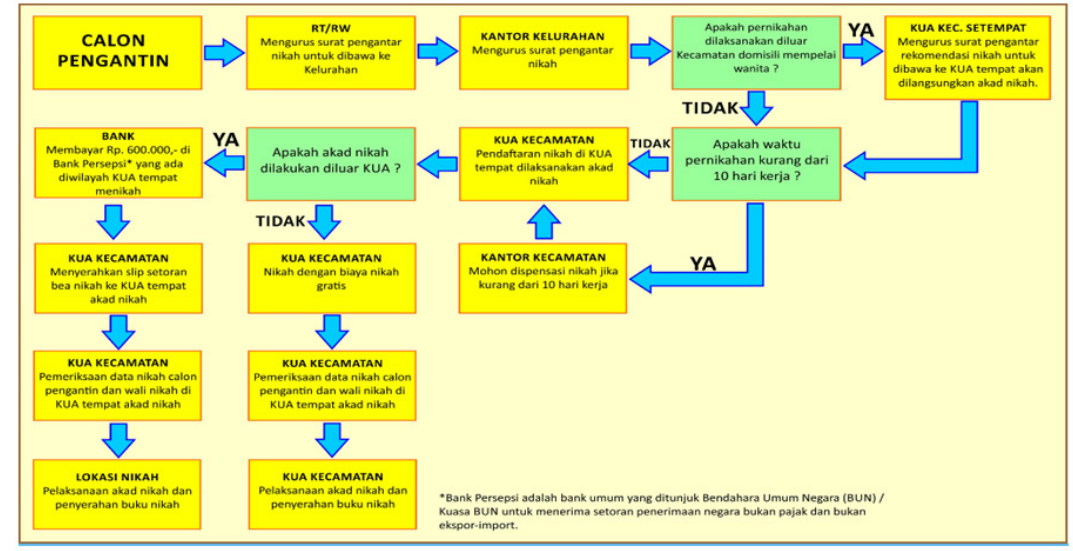

Guna memperjelas bagan di atas, akan diilustrasikan secara sederhana cara kerja badan - badan pelaksana perkawinan sebagaimana disebutkan di atas. Seorang laki-laki, contohnya bernama Mohammad dan seorang perempuan bernama Siti akan menikah dan keluarga kedua belah pihak telah memberikan izin. Langkah pertama yang dilakukan oleh kedua calon pengantin tersebut adalah melaporkan dan meminta surat pengantar menikah kepada 
ketua RT/ RW setempat untuk kemudian dibawa ke desa atau kelurahan.

Pihak desa atau kelurahan kemudian mengeluarkan beberapa surat, yaitu: 1) surat pengatar nikah berupa surat model N1 atau surat keterangan untuk Nikah; 2) surat model $\mathbf{N} 2$ atau surat keterangan asal usul calon pengantin; 3) surat model N3 atau surat persetujuan calon pengantin untuk menikah tanpa ada paksaan; 4) surat model N4 atau surat keterangan tentang orang tua calon pengantin; 5) surat model N5 atau surat izin dari orang tua calon pengantin atas pernikahan anaknya jika di bawah umur 21 tahun sesuai amanat Undang-undang perkawinan. Jika status calon pengantinnya janda mati atau duda mati maka kelurahan akan mengeluarkan surat N6 atau surat keterangan kematian suami/istri, dan yang terakhir adalah surat model N7 atau surat pengantar nikah yang berisi rencana tanggal dan waktu serta tempat pernikahan dan mahar atau mas kawin.

Semua surat di atas dikeluarkan oleh desa/kelurahan dan ditandatangani oleh kepala desa/lurah. Jika si calon pengantin adalah anggota TNI dan POLRI maka harus ada izin komandan atau atasanya secara resmi. Dan jika janda cerai atau duda cerai harus melampirkan surat cerai asli dari pengadilan.

Jika berkas surat model $\mathrm{N}$ di atas sudah terpenuhi dengan dilengkapi KTP, kartu keluarga dan beberapa dokumen penunjang lain maka semua berkas dapat diserahkan ke KUA untuk didaftarkan rencana pernikahannya, dan KUA akan memeriksa berkas-berkas yang diserahkan.

Secara garis besar ada dua pemeriksaan yang dilakukan oleh KUA, pertama adalah memeriksa berkas administrasi calon pengantin apakah sudah terpenuhi atau 
tidak; dan pemeriksaan kedua adalah memeriksa apakah calon pengantIn tidak terhalang secara syariat islam untuk menikah jika agamanya Islam. Jika tidak ada permasalahan administrasi dan halangan secara syari dalam pernikahan maka pernikahan bisa dilaksanakan dan dicatatkan.

Adapun Syarat sah pernikahan dalam hukum Islam merupakan penyempurnaan dari rukun pernikahan. Berdasarkan hal itu, maka syarat sah pernikahan (Ghazali, 2006, hal. 64), adalah:

1. Syarat sah calon suami, sebagai berikut: a) Islam; b) Laki-laki; c) Tidak ada hubungan mahram dengan calon istri; c) Tidak dalam keadaan ihram haji atau umrah; d) Dengan kerelaan sendiri dan bukan paksaan; e) Tidak mempunyai empat orang istri yang sah dalam satu waktu, dan f) Tidak ada halangan pernikahan dengan calon istri.

2. Syarat calon istri, sebagai berikut: a) Islam; b) Perempuan; c) Tidak ada hubungan mahram dengan calon suami; d) Tidak dalam keadaan ihram haji atau umrah; e) Tidak dalam keadaan iddah, dan f) Tidak dalam status pernikahan dengan orang lain.

3. Syarat sah wali sebagai berikut: a) Islam; b) Lakilaki; c) Baligh; d) Dengan kerelaan sendiri dan bukan paksaan; e) Bukan dalam keadaan ihram haji atau umrah; f) Tidak fasik; g) Merdeka.

4. Syarat sah saksi nikah, sebagai berikut: a) Sekurangkurangnya dua orang; b) Islam; c) Berakal; c) Baligh; d) Lelaki; e) Memahami kandungan lafaz ijab dan Kabul; f) Dapat mendengar, melihat, dan berbicara; g) Adil (tidak melakukan dosa-dosa besar dan tidak berterusan melakukan dosa-dosa kecil); h) Merdeka.

5. Syarat sah ijab Kabul, sebagai berikut: a) Syarat sah ijab: i) Tidak boleh menggunakan perkataan sindirin; 
ii) Diucapkan oleh wali atau wakilnya; iii) Tidak diikatkan dengan batas waktu tertentu, dan iv) Tidak secara taklik (tiada sebutan prasyarat sewaktu ijab dilafazkan); b) Syarat sah Kabul: i) Ucapan mestilah sesuai dengan ijab, dan ii) Tidak merupakan perkataan sindiran; iii. Dilafazkan oleh calon suami atau wakilnya (atas sebab-sebab tertentu); iv. Tidak diikatkan dengan batas waktu tertentu; v. Tidak secara taklik (tiada sebutan prasyarat sewaktu Kabul dilafazkan); vi. Menyebut nama calon istri; vii. Tidak diselangi dengan perkataan lain.

Bagaimana halnya denganpengadilan agama? Pengadilan agama akan berperan jika terdapat permasalahan, contohnya jika ternyata salah satu dari calon pengantin tersebut masih di bawah umur, maka KUA akan mengeluarkan surat penolakan pelaksanaan pernikahan dan penolakan mencatatkan pernikahan. Maka, calon pengantin atau keluarganya dapat mengajukan permohonan dispensasi kepada pengadilan agama agar pernikahan dibawah umur dapat dilaksanakan. Jika kemudian pengadilan agama memutuskan mengabulkan permohonan disepensasi nikah di bawah umur oleh calon pengantinataukeluarganya maka KUA wajib melaksanakan pernikahan tersebut dan mencatatkan pernikahannya.

Petugas yang menghadiri peristiwa pernikahan dan mencatatkan peristiwa pernikahan adalah penghulu. Namun, secara syar'i penghulu tidak dapat menikahkan sepasang pengantin jika tanpa izin dan perwakilan dari wali calon pengantin perempuan yang diucapkan dengan akad tertentu.

Lembaga lain yang berperan adalah Kementerian Kesehatan yang memberikan imunisasi untuk calon pengantin yang menjadi salah satu persyaratan pencatatan 
pernikahan. Selanjutnya, lembaga lain yang terlibat proses perkawinan adalah kementerian Keuangan. Bagi calon pengantin yang berencana menikah diluar KUA atau diluar Jam kerja maka harus menyetorkan biaya sebesar Rp 600.000,- kepada negara yang dikelola bersama antara kementerian agama dan kementerian Keuangan.

Ilustrasi di atas memberi gambaran bahwa pernikahan bukanlah kerja satu lembaga KUA saja tetapi merupakan sebuah kerjasama antar lembaga pemerintah lainnya sehingga pernikahan dan pencatatan pernikahan dapat terlaksana. Maka, KUA tidak bisa dijadikan sebagai pihak yang paling bersalah dari banyaknya peristiwa pernikahan dini yang selama ini masih banyak terjadi. KUA memang sebagai lembaga eksekutor dalam pencatatan perkawinan, tetapi jika terdapat manipulasi umur, maka KUA tidak mempunyai otoritas apapun untuk menolaknya. KUA juga tidak bisa memaksa orang tua calon pengantin untuk mengizinkan atau tidak mengizinkan anak - anak mereka yang di bawah umur untuk melakukan perkawinan. Maka, sangat tidak arif jika KUA sebagai badan pelaksana utama perkawinan selalu dipersalahkan.

Upaya - upaya yang telah dilakukan oleh KUA Sukolilo diantaranya secara tegas menolak pengajuan pernikahan yang tidak sesuai syarat dan ketentuan yang berlaku. Juga melakukan pendekatan kepada kepada pihak-pihak yang terlibat dalam pernikahan di bawah umur secara sikum, yaitu tokoh agama dan tokoh masyarakat, serta tokoh perempuan dan pemuda untuk tidak lagi menikahkan mereka yang belum cukup umur meskipun tidak ada larangan dalam agama Islam. Namun, hasilnya belum signifikan dalam menurunkan praktik pernikahan dini di sana.

Belum berhasilnya implementasi kebijakan pembatasan usia minimal perkawinan di Desa Prawoto 
disebabkan oleh beberapa faktor. Meminjam model implementasinya Van Meter dan Van Horn dalam Dwidjowijoto (2006, hal. 128), maka dapat diidentifikasi penyebabnya, yaitu: Pertama, Sumber daya yang minim baik anggaran yang tersedia bagi kegiatan pencegahan pernikahan di bawah umur maupun minimnya jumlah pegawai di KUA Sukolilo; Kedua, Komunikasi antar badan pelaksana kebijakan pembatasan usia pernikahan yang belum nampak, diantaranya minimnya rapat bersama antar aktor-aktor baik dari lembaga publik maupun non publik yang membahas upaya-upaya pencegahan pernikahan di bawah umur dan sikum; Ketiga, Lingkungan sosial dimana badan pelaksana dan sasaran kebijakan berada sangat permisif dan memiliki nilai bahwa semakin cepat anaknya menikah maka semakin membanggakan keluarga. Untuk lebih jelas dapat dilihat pada gambar di bawah ini:

Gambar 2. Faktor-faktor Penentu Implementasi UUP No. 16 Tahun 2019

pasal 7 ayat (1) tentang Pembatasan Usia Minimal Perkawinan

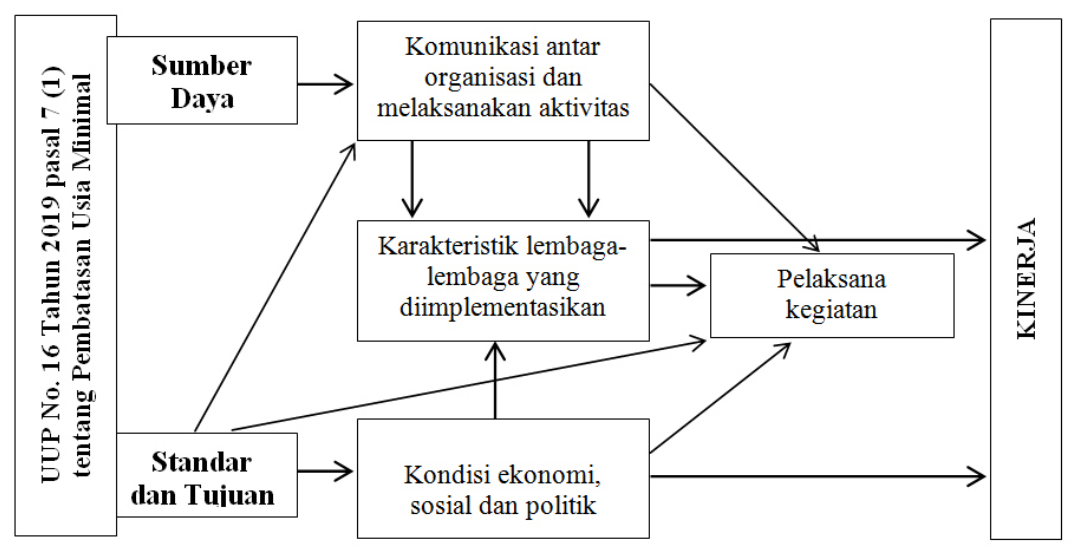

Bagan di atas menunjukkan bahwa Implementasi kebijakan sangat kompleks, dimana satu variabel dapat mempengaruhi variabel yang lain, contohnya: (1) variabel 
sumber daya dapat mempengaruhi lingkungan sosial, ekonomi dan politik; (2) variabel sumber daya juga dapat mempengaruhi komunikasi antar badan pelaksana; (3) variabel lingkungan sosial, ekonomi dan politik dapat mempengaruhi karakteristik badan pelaksana; variabel lingkungan sosial, ekonomi dan politik dapat mempengaruhi sikap pelaksana; (5) variabel lingkungan sosial, ekonomi dan politik dapat mempengaruhi kinerja kebijakan; (6) komunikasi antar badan pelaksana memiliki hubungan yang saling mempengaruhi dengan karakteristik badan pelaksana; (7) komunikasi antar badan pelaksana dapat mempengaruhi sikap pelaksana; (8) karakteristik badan pelaksana dapat mempengaruhi sikap pelaksana; (9) karakteristik badan pelaksana juga dapat mempengaruhi kinerja kebijakan secara langsung, dan seterusnya.

\section{Collaborative Governance Berbasis Gender: Alterna- tive Solusi Pencegahan}

Collaborative Governance berasal dari kata collaborative dan governance. Collaborative atau diterjemahkan sebagai kolaborasi artinya bekerja sama. Secara filosofis, kolaborasi merupakan upaya yang dilakukan oleh berbagai pihak untuk mencapai tujuan yang sama. Menurut Schrage dalam Harley; James \& Blisman (2010, hal. 18) kolaborasi merupakan upaya penyatuan berbagai pihak untuk mencapai tujuan yang sama. Definisi ini mensiratkan bahwa kolaborasi membutuhkan berbagai macam aktor baik individu maupun organisasi yang saling bahu membahu mengerjakan tugas demi tujuan bersama.

Sedangkan governance diterjemahkan sebagai sebuah konsepsi tentang interaksi dalam memerintah, di mana interaksi itu sendiri merupakan hubungan saling menguntungkan antara dua atau lebih aktor atau entitas (Koiman, 2017). Entittas yang dimaksud adalah sejumlah 
organisasi atau institusi baik itu dari pemerintah atau swasta yang dipertautkan (linked together) secara bersama untuk mengurusi kegiatan-kegiatan publik. Mereka dapat bekerja secara bersama-sama dalam sebuah jejaring antar negara.

Berdasar dua definisi di atas, maka Collaborative Governance menurut Ansel dan Gash (2007, hal. 544) adalah sebuah strategi baru dalam tata kelola pemerintahan yang membuat beragam pemangku kebijakan berkumpul di forum yang sama untuk membuat sebuah consensus bersama. Selanjutnya Ansel Gash mendefinisikan collaborative governance sebagai sebuah aransemen tata kelola pemerintahan yang mana satu atau lebih institusi publik secara langsung melibatkan actor nonpemerintahan dalam sebuah proses pembuatan kebijakan kolektif yang bersifat formal, berorientasi consensus, dan konsultatif dengan tujuan untuk membuat atau mengimplementasikan kebijakan publik, mengelola program atau asset publik.

Ada enam kata kunci yang dapat disimpulkan dari definisi di atas, yaitu: 1) Forum diinisiasi dan dilaksanakan oleh lembaga public maupun aktor-aktor dalam lembaga publik; 2) Peserta dalam forum juga actor non publik; 3) Peserta terlibat secara langsung dalam pembuatan dan pengambilan keputusan; 4) Forum terorganisir secara formal dan pertemuan diadakan secara bersama-sama; 5) Forum berorientasi pada konsensus; dan 6) Kolaborasi berfokus pada kebijakan publik maupun manajemen publik.

Seigler (2011, hal. 968-970) menyampaikan delapan prinsip utama dalam penerapan collaborative governance: 1 ) Warga masyarakat harus turut dilibatkan dalam produksi barang public; 2) Masyarakat harus mampu memobilisasi sember daya dan aset untuk memecahkan masalah publik; 3) tenanga professional harus berbagi keahlian mereka 
dengan untuk memberdayakan warga masyarakat; 4) Kebijakan harus menghadirkan musyawarah public; 5) Kebijakan harus mengandung kemitraan kolaboratif yang berkelanjutan; 6) Kebijakan harus strategis; 7) Kebijakan harus mengubah kelembagaan untuk pemberdayaan masyarakat dan pemecahan masalah publik; 8) Kebijakan harus mengandung akuntabilitas.

Model collaborative governance menurut Ansell dan Gash (Gash, 2007, hal. 550-561) terdiri dari empat variabel utama, yaitu kondisi awal, desain kelembagaan, kepemimpinan dan proses kolaboratif. Tahapan pada proses kolaboratif meliputi dialog face-to-face, membangun kepercayaan, komitmen terhadap proses, memahami bersama dan hasil sementara. Semua collaborative governance dibangun atas dialog face-to-face antar para stakeholders. Sebagai suatu proseskonsensus, dialoglangsung diperlukan para stakeholders untuk mengidentifikasi peluang untuk keuntungan bersama.

Berdasar pada definisi dan berbagai konsep di atas, maka collaborative governance menjadi alternatif solusi yang tepat dalam pelaksanaan kebijakan pembatasan usia minimal perkawinan yang bertujuan mencegah terjadinya perkawinan di bawah umur. Sebab pada konsep collaborative governance ini menciptakan "kepemilikan bersama" terhadap masalah perkawinan dini yang tak kunjung berenti terjadi. Kolaborasi yang dimaksud adalah antara lembaga publik yang terdiri KUA Sukolilo sebagai leading sector kebijakan, Kepala Desa Prawoto, Ketua RT, dan Pengadilan Agama Kabupaten Pati, dengan lembaga atau aktor non publik seperti masyarakat Dukuh Ploso Kerep, tokoh agama,tokoh organisasi kemasyarakatan yang ada di Desa Prawoto seperti Nahdlatul Ulama, Anshor, Muslimat NU, Fatayat NU, Pimpinan jamiyyah tahlil baik bapak-bapak, ibu-ibu, maupun remaja putra dan putri, Ikatan 
Putra Nahlatul Ulama (IPNU), Ikatan Putri-Putri Nahdlatul Ulama (IPPNU), serta perwakilan pemuda lainya seperti Karang Taruna.

Bentuk kolaborasi dapat dimulai dengan inisiasi pembentukan forum bersama oleh KUA Sukolilo yang bertujuan untuk penyamaan persepsi tentang kebijakan pembatasan usia minimal perkawinan, membangun komitmen bersama, dan aksi-aksi konkrit pencegahan. Adanya forum ini juga mampu menyelesaikan persoalan komunikasi yang selama ini tidak terjadi antara lembagalembaga tersebut.

Guna mengurangi dan menghilangkan kesenjangan gender yang selama ini terjadi dalam pelaksanaan kebijakan PUP, maka forum ini harus memulai dengan mempertimbangkan kesetaraan gender dan issue gender setiap ada pertemuan ditandai dengan tidak adanya diskriminasi antara perempuan dan laki-laki dalam mengakses, berpartisipasi, mengontrol, dan memperoleh manfaat yang setara dan adil.

Setelah terbentuknya forum tersebut maka proses kolaborasi dimulai dengan penggerakan prinsip bersama, memotivasi bersama dan pembentukan kapasitas dalam melakukan tindakan kolaborasi, kemudian melakukan aksi bersama.

Aksi bersama yang harus segera dilakukan adalah adanya deklarasi "tolak bersama pernikahan dini dan pernikahan sirri". Aksi bersama ini akan memberikan early warning agar masyarakat di sana tidak melakukanya. Deklarasi ini kemudian bisa diikuti dengan sosialisasi di masing-masing organisasi atau lembaga yang ada bahwa pelanggaran terhadap undang-undang perkawinan mengenai batas usia minimal adalah bentuk perlawanan terhadap negara. Juga disosialisasikan tentang bahaya 
dilakukanya pernikahan dini baik bagi rumah tangga, kerentanan fungsi reproduksi perempuan, juga terenggutnya berbagai hak sebagai anak. Jika sosialisasi ini dilakukan secara massif oleh ormas-ormas di Desa Prawoto maka akan lebih efektif dibandingkan kegiatan yang dilakukan secara formal seperti workshop maupun seminar seperti yang selama ini dilakukan.

\section{Simpulan}

Upaya pencegahan terjadinya perkawinan dini sudah dilaksanakan oleh KUA Sukolilo melalui pelaksanaan kebijakan Pembatasan Usia Minimal Perkawinan diantaranya dengan secara tegas melakukan penolakan terhadap berkas pengajuan perkawinan yang tidak memenuhi syarat minimal perkawinan. Namun, upaya tersebut hasilnya kurang signifikan sebab pintu masuk berbagai persoalan seperti manipulasi usia, atau pernikahan di bawah umur secara sikum, berada pada otoritas lembaga lain. Collaborative Governance berbasis gender menjadi solusi alternatifnya dengan melibatkan masyarakat, pemuda, tokoh agama, Ketua RT, Kepala Desa, Kecamatan, KUA, dan Pengadilan Agama dalam pelaksanaan kebijakan Pembatasan Usia Minimal Perkawinan. Diawali dengan pembentukan forum bersama dengan mempertimbangkan kesetaraan gender yang memberikan akses, partisipasi, kontrol, dan manfaat yang setara antara laki-laki dan perempuan, dilanjutkan dengan membangun komitmen bersama dan aksi-aksi nyata merupakan alternatif solusi yang paling memungkinkan dilakukan dan efektif untuk pencegahan perkawinan dini dan terutama yang dilakukan dengan sirri. 


\section{Daftar Pustaka}

Asadullah, M. Niaz; Wahhaj, Z. (2016). Child Marriage Law and Freedom of Choice in Bangladesh. Economic $\mathcal{E}$ Political Weekly, I(3), 24-26.

Bappenas \& KPP. (2007). Gender Analysis Pathway. Jakarta Indonesia.

Chandra, M. (2018). Aspek Perlindungan Anak Indonesia: Analisis tentang Perkawinan di Bawah Umur. Jakarta Indonesia: Prenadamedia Group.

Dewi, S. M. (2016). Fenomena Pernikahan Sikum dan Di Bawah Umur Di Dukuh. PALASTREN, 9(2), 325340. https://doi.org/http://dx.doi.org/10.21043/ palastren.v9i2.2442

Dwidjowijoto, R. N. (2006). Kebijakan Publik untuk Negara-negara Berkembang Model-model Perumusan, Implementasi, dan Evaluasi. Jakarta indonesia: PT Elex Media Komputindo.

Gash, A. dan. (2007). Collaborative Governance in Theory and Practice,. Journal of Public Administration.

Ghazali, A. R. (2006). Figh Munakahat (2 ed.). Jakarta Indonesia: Kencana Prenada Media Group.

Harley; James \& Blisman, N. (2010). An Anatomy of Collaboration Within the Online Environment dalam Anandarajan, Murugan (ed), e-Research Collaboration: Theory, Techniques and Challenger. Heidelberg: Springer International Publishing AG.

Jensen, R., \& Thornton, R. (2014). Early Female Marriage in the Developing World. Gender \& Development, 11(2), 9-19. https:/ / doi.org/10.1080/741954311 
Koiman. (2017). Governing as Governance. Sosiohumaniora, 19(1).

KPPA, H. (2016). Cegah Perkawinan Usia Anak.

Kustini. (2013). Menelusuri Makna Di Balik Fenomena Perkawinan Di Bawah Umur dan Perkawinan Tidak Tercatat. (Kustini, Ed.) (I). Jakarta Indonesia: Puslitbang Kehidupan Keagamaan Badan Litbang dan Diklat Kementerian Agama RI.

Marbun, S.F \& Mahfud, M. . (2009). Pokok-pokok Hukum Administrasi Negara. Yogyakarta: Liberty.

Mikhail, S. L. B. (2010). Child Marriage and Child Prostitution: Two forms of sexual exploitation. Gender \& Development, 10(1), 42-49. https://doi. org/10.1080/13552070215896

MUI. (2009). Ijma'Ulama (keputusan Ijtima Ulama Komisi fatwa se-Indonesia III). Jakarta Indonesia.

Seigler. (2011). Renewing Democracy by Engaging Citizen in Shared Governance. Public Administration Review.

Statistik, B. P. (2017). Situasi Perkawinan Anak di Indonesia Tahun 2017. Jakarta Indonesia.

Sutendi, A. (2010). Hukum Perizinan dalam Sektor Pelayanan Publik. Jakarta Indonesia: Sinar Grafika. 